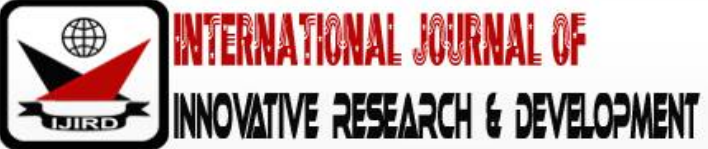

ISSN 2278 - 0211 (Online)

\section{Effects of Relative Humidity and Wind Speed on a Parabolic Trough Collector (Model TE 38) in Bauchi, Nigeria}

Achekuogene Saliu Nihad
Senior Engineer, Department of Works \& Maintenance, Auchi Polytechnic, Auchi, Nigeria
Imonigie Arnold Osigbeme
Lecturer, Department of Electrical \& Electronic Auchi Polytechnic, Auchi, Nigeria
Shuaibu-Sadiq Munirah
Principal Technologist, Department of Electrical \& Electronic, Auchi Polytechnic, Auchi, Nigeria
Nmoye Ruth
CEO, Private Practitioner, Creative plus Engineering Solution, Nigeria

\begin{abstract}
:
One of the challenges facing development in Nigeria is the lack of adequate energy supply. Solar energy is one of the renewable sources that have high potentials to accelerate development especially in the northern part of Nigeria like Bauchi. One of the proven solar energy collectors is the parabolic trough collector system which can be utilized for thermal steam generation. The aim of this study is to investigate the effects of relative humidity and wind speed on the performance of parabolic trough collector system (Model TE38) in Bauchi. The relative humidity and wind speed were observed using the metrological facilities within Bauchi State. Daily record of temperatures of the enveloping glasscover, the fluid and the receiver tube of the parabolic trough collector were monitored. The values obtained were used to calculate the hourly thermal efficiency of the solar parabolic-trough collector. It was discovered that, the higher the temperature of the absorber-tube, the higher was the radiative heat-loss which also affects the efficiency. The collector efficiency increased with time up to a maximum of $96.41 \%$ at 13:00 hours, thereafter, the efficiency starts decreasing with time to a minimum of $93.68 \%$ at $16: 00$ hours, within the period under review. The parabolic trough collector system was found viable for solar energy utilization since the effect of relative humidity and wind speed was minimal.
\end{abstract}

Keywords: Relative humidity, wind speed, parabolic trough collector (Model TE38), Bauchi State

\section{Introduction}

Energy is the motive force of economic development. Energy demand gradually increases with population expansion and industrial development. However, energy consumption, at present is mostly based on fossil sources (petroleum, coal, and natural gas), which are limited and generally decreasing (Ettah et al, 2012). The environmental degradation and deterioration of living condition occasioned by emissions currently generated by the use of fossil fuels are the sources of serious environmental problems, such as acid rain, greenhouse effect and ozone layer depletion, which in many cases are irreversible (Dincar, 2003). The demand for renewable and clean energy is increasing. In recent years the development of new technologies utilizing renewable and clean energy has become an important area of worldwide research (Zhou et al, 2008). The increasing use and promotion of renewable energy technologies such as biomass, wind, hydroelectricity, solar thermal and solar electricity, seems to be a viable solution to environmental problem caused by other energy sources (Raban, 2005). Of the many technologies utilizing solar energy, the most attractive ones seem to be: solar photovoltaic technology and solar concentrating thermal power technology among which is parabolic trough collectors.

Parabolic trough technology is currently the most proven solar thermal electric technology (www.pubs.asce.org). Parabolic trough collector system reflects the incoming direct radiation with concentration value of around 80 to the absorber tube (Horst, 2012). The focused radiation is absorbed on a blackened small receiver, which may be insulated to reduce thermal losses (Ojukwu et al 2006). The intensity of the sun determines the amount of power that could be generated in conjunction with the capacity of the solar parabolic trough collector system (Onwuka et al 2002). Owing to variation in geography and the sun`s position with respect to any location, the available solar radiation varies from places to places. It is this variation in time that makes it imperative for solar radiation values in any location to be determined and applied in the same location (Agbo et al 2007). Since the solar radiation reaching the earth`s surface depends upon climatic conditions of the place, to this effect, the relative humidity and wind speed of Bauchi is under consideration in this study. Relative humidity is the ratio (expressed as a percentage) of the amount of water vapor the air can hold at a given temperature. If air is relatively dry compared to its capacity, the relative humidity percentage is said to be low, if it is 
relatively moist, the percentage is said to be high. Relative humidity varies because of evaporation, condensation and temperature changes (Olusegun et al 1980). Wind is generated by the movement of air from regions of high pressure to regions of low pressure. It is therefore estimated that between 1.5 to $2.5 \%$ of the global solar radiation receive on the surface of the earth is converted to wind. Bauchi state lies between $9.3^{\circ}$ and $12.3^{\circ}$ North of the equator and $8.5^{\circ} \& 11^{\circ}$ east of the Greenwich meridian. The state spans through three district vegetation zones which are the North guinea savannah, Sudan savannah and Sahel savannah with Sudan savannah dominating (Adeyemi et al, 2007). With the increasing demand for solar electric power generation especially in the areas of parabolic trough utilization, it is pertinent to know the effect of relative humidity and wind speed on its performance using meteorological data in Bauchi state.

\subsection{Scope of Study}

The area under study is limited to Bauchi town using a modern and meteorological data in Bauchi town of the state. The choice of Bauchi is because it represents a typical setting in the north east, and spans three distinct vegetation zones which are the northern guinea savannah, Sudan savannah and Sahel savannah with the Sudan savannah dominating (Adeyemi et al, 2007).

\subsection{Significance}

It is a well-known fact that relative humidity and wind speed will have an effect on the performance of a parabolic trough system, but the extent of this effect is unknown particularly within Bauchi state. Hence, the research will provide the much-needed information on the event of establishing a parabolic trough collector project within the state. In this case, the parameters obtain from the model will only be changed to accommodate the design of a plant. Parabolic trough system provides an alternative source of power generation with clean and environmentally safe energy that is sustainable as long as we have the sun. The sun`s energy, by its nature has renewable and sustainable energy flow to the earth`s surface. This single quality assures man of an endless energy supply if properly harnessed. (Obienusi, 2006)

\subsection{Aim and Objective}

The aim of this research is to investigate the effect of relative humidity and wind speed on the performance of Parabolic-trough Collector (Model TE38) in Bauchi town.

The objectives are:

- To provide useful parameters on relative humidity and wind speed in Bauchi state and their effect on the performance of a Parabolic-trough collector system (model TE38).

- It is also geared at introducing an enhanced method of electric power generation whose main objective is the creation of an alternative to the long stressed and over dependent hydro-electric power and fossil fuel as the main source of generating power.

\section{Literature Review}

The sun`s energy, by its nature has renewable and sustainable energy flow reaches the atmosphere and the earth`s surface as sunlight. The energy built-up of the sunlight reaching the atmosphere is constant, usually called solar constant, with a value of 1367 Watts $/ \mathrm{M}^{2}$. However, due to earth`s rotation and revolution, the amount of sun`s energy intensity varies greatly with latitude, time of the day, and season of the year (Obienusi, 2006). Solar energy is one of the most abundant sources of energy on earth. It is also considered one of the cleanest sources of energy available. This form of energy does not need to be extracted, transported to and fro, nor is any costly exploration required. The development and application of solar energy collection and conversion systems depends on the amount and characteristics of solar radiation they receive.

All the solar radiations emitted from the sun reach the earth in an indirect way. Upon entering the atmosphere, the extraterrestrial beam is scattered by air molecules, water droplets, dusts and other aerosol particles, and partially absorbed by atmospheric gases and water vapour, thereby removing large percentage of energy from it (Dandakouta et al, 2007).

Solar technology is not new as thought by many people. The technology has evolved over time. Its history spans from the $3^{\text {rd }}$ century BC to today. The idea of using solar energy collectors to harness the sun`s power is recorded from the prehistoric time when at $212 \mathrm{BC}$ the Greek scientist/physician Archimedes devised a method to burn the Roman fleet. Archimedes reportedly set the attacking Roman fleet on fire by means of concave metallic mirror in the form of hundreds of polished shields; all reflecting on the same ship (Kalogirou, 2004). Amazingly, the very first application of solar energy refer to the use of concentrating collectors, which are by their nature (accurate shape construction) and the requirement to follow the sun, more 'difficult' to apply.

During the $18^{\text {th }}$ century, solar furnaces capable of melting iron, copper and other metals were being constructed of polished-iron, glass lenses and mirrors. The first conversion of sunlight to electricity was one percent efficient and was performed by Smith in 1873. This means that $1 \%$ of the incoming was converted into electricity. He further discovered that selenium was sensitive to light (Igboekwe et al 2006). In 1839, a young man named Alexander-Edmond Bequerel becomes the first to discover the photovoltaic effect. But in nearly forty years later, William Grylls Adams in 1876 developed a more sophisticated solar cell. He discovered that a solid material called selenium produced electrical currents when exposed to the light of the sun. Few years later, Gerald Pearson of Bell laboratories developed a solar cell using silicon instead of selenium. This was a huge step towards the advanced solar panels we use today (Kalogirou, 2004).

The search for alternative energy sources relating to solar power continues, and in 1875, Mouchot made a notable advance in solar collector design by making one in the form of a truncated cone reflector. Mouchot collector consisted of 
silver-plated metal plates and had a diameter of $5.4 \mathrm{~m}$ and a collecting area of $18.6 \mathrm{~m}^{2}$. Abel Pifre was a contemporary of Mouchot who also made solar engines. Pifre`s solar collectors were parabolic reflectors made of very small mirrors. Around 1883, Captain John Ericsson used a longitudinal parabolic concentrator to operate a steam engine for pumping water. His experiment with solar engine never advanced beyond the prototype stage (Kalogirou, 2004). Alber Einstein explanation in 1905 of the photoelectric effect, raised peoples hopes that new solar electricity at higher efficiency would become feasible. The world`s very first documented parabolic-trough plant was built in Maadi, Egypt in 1913. The system consisted of five collectors oriented in a north-south direction with a mechanical tracking system. Each collector was $62 \mathrm{~m}$ in length and $4 \mathrm{M}$ width with spacing of $7.6 \mathrm{M}$. The system generated steam that was used to power water pump for irrigation purposes. The system is shown in Figure 1(Khaled, 2012).

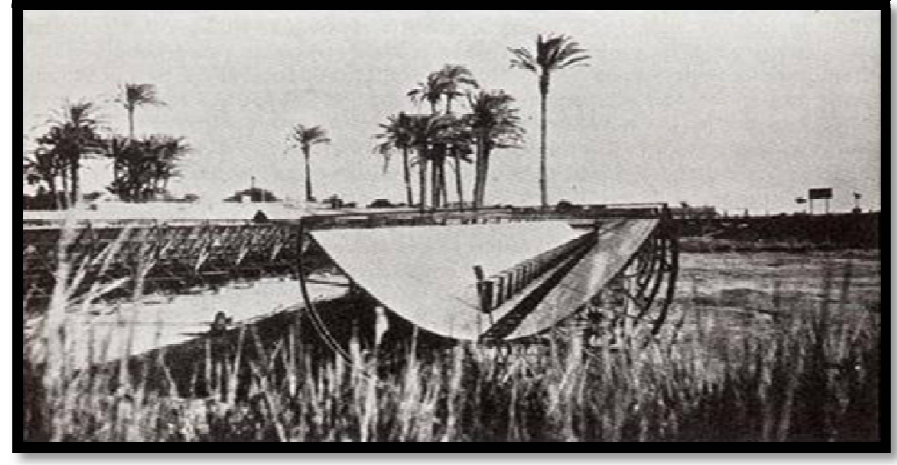

Figure 1: Shuman-Boys Solar Power Plant, Egypt

Recent development of parabolic-trough power plant took place in the US in mid-1970s and in Europe in 1980s. Parabolic trough collectors capable of generating temperatures greater than $500^{\circ} \mathrm{C}\left(932^{\circ} \mathrm{F}\right)$ were initially developed for industrial process heat (IPH) applications. Much of the early development was conducted by or sponsored through Sandia National Laboratories in New Mexico. The development was culminated with the construction of Small Solar Power Systems Project/Distributed Collector System (SSPS/DCS) by the International energy agency (IEA) in Tabernas, Spain, 1981. This facility consisted of two parabolic-trough solar fields with a total mirror aperture area of $7602 \mathrm{~m}^{2}$. The fields used the single-axis tracking Acurex collectors and the double-axis tracking parabolic-trough collectors developed by M.A.N. of Munich, Germany. In 1982, Luz International Limited (Luz) developed a parabolic-trough collector for IPH applications. Starting in 1985, Luz built eight parabolic trough power plants in California, U.S. The characteristics of the plants are shown in table 2.1. The plants are designed to produce full electrical power with steam supplied either by solar field or by natural gas (via the gas-fired boiler). There are other operational parabolic trough power plants in the U.S. such as Nevada Solar One plant with 72MWe net capacities and Martin Next Generation Solar Energy Center plant with a net capacity of 75MWe.

\begin{tabular}{|c|c|c|c|c|c|c|c|}
\hline $\begin{array}{l}\text { SEGs } \\
\text { Plant }\end{array}$ & $\begin{array}{c}1^{\text {st }} \text { Year } \\
\text { operation }\end{array}$ & $\begin{array}{c}\text { Net } \\
\text { output } \\
\text { (MW) }\end{array}$ & 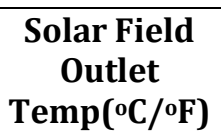 & $\begin{array}{c}\text { Solar } \\
\text { Field } \\
\left.\text { Area(m }{ }^{2}\right)\end{array}$ & $\begin{array}{l}\text { Solar } \\
\text { Turbine } \\
\text { Eff. (\%) }\end{array}$ & $\begin{array}{l}\text { Fossil } \\
\text { Turbine } \\
\text { Eff. (\%) }\end{array}$ & $\begin{array}{l}\text { Annual } \\
\text { Output } \\
\text { (MWh) }\end{array}$ \\
\hline I & 1985 & 13.8 & $307 / 585$ & 82.960 & 31.5 & - & 30.100 \\
\hline II & 1986 & 30 & $316 / 601$ & 190.338 & 29.4 & 37.3 & 80.500 \\
\hline III\& VI & 1987 & 30 & $349 / 660$ & 230.300 & 30.6 & 37.4 & 92.780 \\
\hline V & 1988 & 30 & $349 / 660$ & 250.500 & 30.6 & 37.4 & 91.820 \\
\hline VI & 1989 & 30 & $390 / 734$ & 188.000 & 37.5 & 39.5 & 90.850 \\
\hline VII & 1999 & 30 & $390 / 734$ & 194.280 & 37.5 & 39.5 & 92.646 \\
\hline VIII & 1990 & 80 & $390 / 734$ & 464.340 & 37.6 & 37.6 & 252.750 \\
\hline IX & 1991 & 80 & $390 / 734$ & 483.960 & 37.6 & 37.6 & 256.125 \\
\hline
\end{tabular}

Table 1: Characteristics of Solar Electric Generating Systems (SEGS) I through IX

Http://Www.Solarpaces.Org/CSP_Technology/Docs/Solar_Trough.Pdf

Although several parabolic-trough developers sold IPH systems in the 1970s and 1980s, they generally found two barriers to successful marketing of their technologies. First, there was a relatively high marketing and engineering effort required for even small projects. Secondly, most potential industrial customers had cumbersome decision-making processes which often resulted in a negative decision after considerable effort had already been expanded. (www.solartrough.com/pdf).

However, since June 1992 Rio de Janeiro United Nations Conference on Environment and Development (UNCED), the issue of Energy Efficiency has gained prominence among nations in their energy development strategies. As outlined in Agenda 21, chapter 9, the conference agreed that current patterns of production and utilization of energy cannot be sustained, and that one of the ways of promoting sustainable development is to reduce adverse effect on the atmosphere from the energy sector (Jesuleye et al 2008). This calls for strong campaign for greater reliance on environmentally sound 
energy systems, particularly new and renewable sources of energy to provide solution to the world energy demands estimated to double within the next 20 years. With depletion of fossil fuels at a faster rate than ever before and serious concerns by governments worldwide for global warming and its associated climatic change, parabolic-trough technology as an elegant and effective renewable energy resource is increasingly being seen as a promising candidate for provision of clean and sustainable power.

\subsection{Solar Collectors}

Solar energy collectors are special kind of heat exchangers that transform solar radiation energy to internal energy of the transport medium. The major component of any solar system is the solar collector. This is a device which absorbs the incoming solar radiation, converts it into heat, and transfers this heat to a fluid (usually air, water, or oil) flowing through the collector. The solar energy thus collected is carried from the circulating fluid either directly to the hot water or space conditioning equipment or to a thermal energy storage tank from which can be drawn for use at night and/or cloudy days. There are basically two types of solar collectors: non-concentrating or stationary and concentrating. A non-concentrating collector has the same area for intercepting and for absorbing solar radiation, whereas a sun-tracking concentrating solar collector usually has concave reflecting surfaces to intercept and focus the sun's beam radiation to a smaller receiving area, thereby increasing the radiation flux. A large number of solar collectors are available in the market. A comprehensive list is shown in Table 2.

\subsection{Stationary Collectors}

Solar energy collectors are basically distinguished by their motion, i.e. stationary, single axis tracking and two axes tracking, and the operating temperature. Initially, the stationary solar collectors are examined. These collectors are permanently fixed in position and do not track the Sun movement. Three types of collectors fall in this category:

- $\quad$ Flat plate collectors (FPC);

- Stationary compound parabolic collectors (CPC);

- $\quad$ Evacuated tube collectors (ETC).

\begin{tabular}{|c|c|c|c|c|}
\hline Motion & Collector Type & Absorber Type & $\begin{array}{c}\text { Concentration } \\
\text { Ratio }\end{array}$ & $\begin{array}{c}\text { Indicative Temt. } \\
\text { Range (8C) }\end{array}$ \\
\hline \multirow[t]{3}{*}{ Stationary } & $\begin{array}{l}\text { Flat plate collector } \\
\text { (FPC) }\end{array}$ & Flat & 1 & $30-80$ \\
\hline & $\begin{array}{l}\text { Evacuated tube } \\
\text { collector (ETC) }\end{array}$ & Flat & 1 & $50-200$ \\
\hline & $\begin{array}{l}\text { Compound parabolic } \\
\text { collector (CPC) }\end{array}$ & Tubular & $1-5$ & $60-240$ \\
\hline \multirow[t]{4}{*}{$\begin{array}{c}\text { Single-axis } \\
\text { tracking }\end{array}$} & & & $5-15$ & $60-300$ \\
\hline & $\begin{array}{c}\text { Linear Fresnel reflector } \\
\text { (LFR) }\end{array}$ & Tubular & $10-40$ & $60-250$ \\
\hline & $\begin{array}{c}\text { Parabolic trough } \\
\text { collector (PTC) }\end{array}$ & Tubular & $15-45$ & $60-300$ \\
\hline & $\begin{array}{l}\text { Cylindrical trough } \\
\text { collector (CTC) }\end{array}$ & Tubular & $10-50$ & $60-300$ \\
\hline \multirow[t]{2}{*}{$\begin{array}{l}\text { Two-axes } \\
\text { tracking }\end{array}$} & $\begin{array}{c}\text { Parabolic dish reflector } \\
\text { (PDR) }\end{array}$ & Point & $100-1000$ & $100-500$ \\
\hline & $\begin{array}{l}\text { Heliostat field collector } \\
\text { (HFC) }\end{array}$ & Point & $100-1500$ & $150-2000$ \\
\hline
\end{tabular}

Table 2: Solar Energy Collectors

Note: Concentration Ratio Is Defined as the Aperture Area Divided by the Receiver/Absorber Area of the Collector (Kalogirou 2004)

\subsection{Concentrating Collectors}

In concentrating collectors' solar energy is optically concentrated before being transferred into heat. Concentration can be obtained by reflection or refraction of solar radiation by the use of mirrors or lens. The reflected or refracted light is concentrated in a focal zone, thus increasing the energy flux in the receiving target. Concentrating collectors can also be classified into non-imaging and imaging depending on whether the image of the sun is focused at the receiver or not. The concentrator belonging in the first category is the CPC whereas all the other types of concentrators belong to the imaging type. The collectors falling in this category are:

- Parabolic trough collector;

- Linear Fresnel reflector (LFR);

- Parabolic dish;

- Central receiver. 


\subsubsection{Parabolic Trough Technology}

Parabolic trough power plants uses a curved, mirrored trough which reflects the direct solar radiation onto a glass tube containing a fluid (also called a receiver, absorber or collector) running the length of the trough, positioned at the focal point of the reflectors. The trough is parabolic along one axis and linear in the orthogonal axis. For change of the daily position of the sun perpendicular to the receiver, the trough tilts east to west so that the direct radiation remains focused on the receiver. However, seasonal changes in the angle of sunlight parallel to the trough does not require adjustment of the mirrors, since the light is simply concentrated elsewhere on the receiver. Thus, the trough design does not require tracking on a second axis (www.sunraysolar.com). In general, the design of the solar field depends on plant and collector size, the temperature and pressure losses in the piping system and the specific ambient conditions. Parabolic trough fields can be erected in any direction, but erected in a north-south direction leads to the highest possible energy yield over the year while an east-west orientation smooths down the seasonal fluctuations.

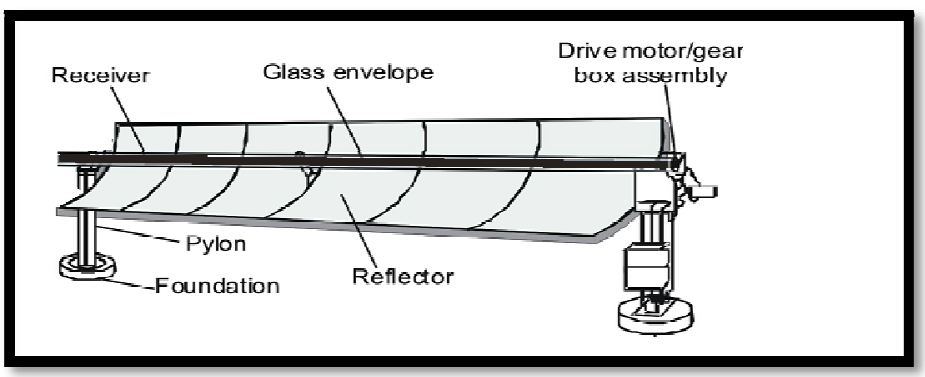

Figure 2: Assembled Solar Parabolic-Trough Concentrator

\subsubsection{Absorber/Receiver}

The receiver of a parabolic trough is linear. Usually, a tube is placed along the focal line to form an external surface receiver (Fig. 2.4). The size of the tube, and therefore the concentration ratio, is determined by the size of the reflected sun image and the manufacturing tolerances of the trough. The surface of the receiver is typically plated with selective coating that has a high absorptance for solar radiation, but a low emittance for thermal radiation loss. A glass cover tube is usually placed around the receiver tube to reduce the convective heat loss from the receiver, thereby further reducing the heat loss coefficient (see fig 2.5). A disadvantage of the glass cover tube is that the reflected light from the concentrator must pass through the glass to reach the absorber, adding a transmittance loss of about 0.9 , when the glass is clean. The glass envelope usually has an anti-reflective coating to improve transmissivity. One way to further reduce convective heat loss from the receiver tube and thereby increase the performance of the collector, particularly for high temperature applications, is to evacuate the space between the glass cover tube and the receiver.A fluid (also called heat transfer fluid) passes through the receiver and becomes very hot. Common fluids are synthetic oil, molten salt and pressurized steam. The fluid containing the heat is transported to a heat engine where about a third of the heat is converted to electricity (Kearney et al 1988).

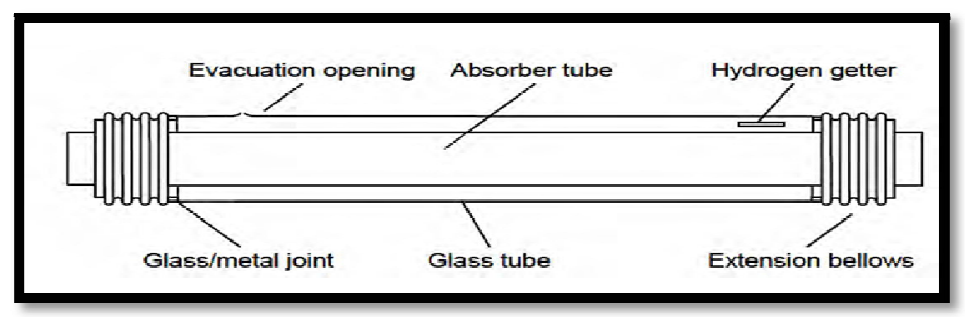

Figure 3: Absorber Tube of a Parabolic Trough Collector

\section{Methodology}

\subsection{Data of Solar Parabolic Collector (Model TE.38)}

- Inclination and azimuth - Adjustable

- Parabolic reflector - Stainless Steel

- Aperture width (W) - 800mm $(0.8 \mathrm{~m})$

- $\quad$ Focal length (f) - $487 \mathrm{~mm}(0.487 \mathrm{~m})$

- Aperture area $(\mathrm{Aa})-0.24 \mathrm{~m}^{2}$

\subsection{Collector`s Data}

The collector set-up was placed in the premises of ZERI Center of the Abubakar Tafawa Balewa University, Bauchi, Nigeria, where an open air and a clear view of the sky are perceived to be good in other to avoid reduction in efficiency. Due to the permissible working hours at the ZERI center, the experimentation time was from 09:00-16:00 hours daily for 7 days. A digital thermometer was used to measure the hourly temperature and the readings taken included; hourly 
temperature of the enveloping glass-cover, hourly temperature of the absorber-tube, hourly temperature of the fluid and hourly ambient temperature. The values obtained are used to calculate hourly thermal efficiency of the solar parabolictrough concentrating collector (Model TE .38).

\subsection{Climatic Data}

The climatic data used for the study are the monthly mean values of relative humidity and wind speed. Bauchi is one of the major cities in north east part of the country situated within the savannah and lies between 9.30 and 12.30 north of the equator and 8.50 and 110 east of the Greenwich meridian. The relative humidity and wind speed data was obtained from the Nigeria meteorological station Bauchi. For each day, the hourly data was averaged over the hours of the days to give the average values for the week, called the hourly average value for the week.

\subsection{Regression Data}

The values obtained from the climatic data and the collector's data was used to calculate the hourly thermal efficiency of the solar parabolic-trough collector system. The relative humidity and wind speed were compared with the efficiency obtained to draw out conclusions.

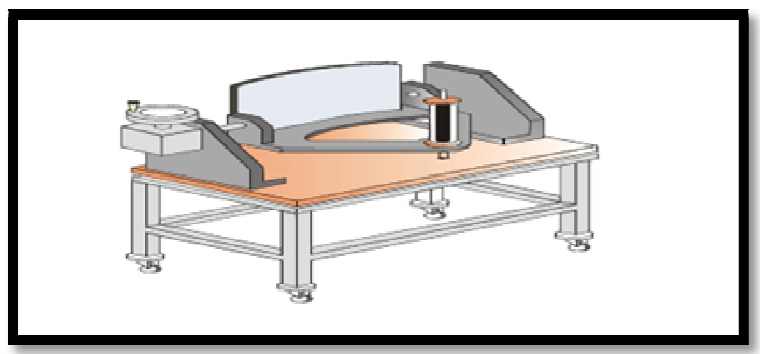

Figure 4: Solar Parabolic-Trough Collector Model TE 38

The Energy balance equations considered for SPTC are the heat-energy-gain, the heat-energy-loss and the heatenergy-transfer between the components. The total heat-energy loss in the system $\left(\mathrm{Q}_{\text {losses }}\right)$ is considered as the sum of the radiative heat-loss from the surface of the enveloping glass-cover to the surroundings $\left(\mathrm{q}_{\mathrm{r}_{2}}\right)$, the convective heat-loss from the surface of the enveloping glass-cover to the surroundings $\left(q_{c}\right)$, the radiative heat-loss from the surface of the absorber-tube $\left(\mathrm{q}_{\mathrm{r}_{1}}\right)$ and the conductive/convective heat-loss inside the absorber-tube $\left(\mathrm{q}_{1}\right)$. This can be expressed as:

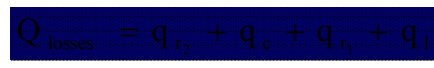

The hourly radiative heat-loss from the enveloping glass-cover by radiation to the surroundings is given by:

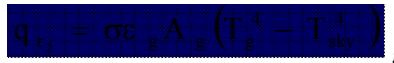

where $\sigma=$ Stefan-Boltzman's constant, $\varepsilon_{\mathrm{g}}=$ emittance of the enveloping glass-cover material, $\mathrm{A}_{\mathrm{g}}=$ surface area of the enveloping glass-cover, $\mathrm{T}_{\mathrm{g}}=$ temperature of the enveloping glass-cover, and $\mathrm{T}_{\text {sky }}=$ sky temperature. The sky temperature can be expressed as

(Duffie et al, 1974),

where $\mathrm{T}_{\text {surr }}=$ ambient temperature. The hourly convective heat-loss from the enveloping glass-cover to the surroundings is computed using Equation 4 as follows:

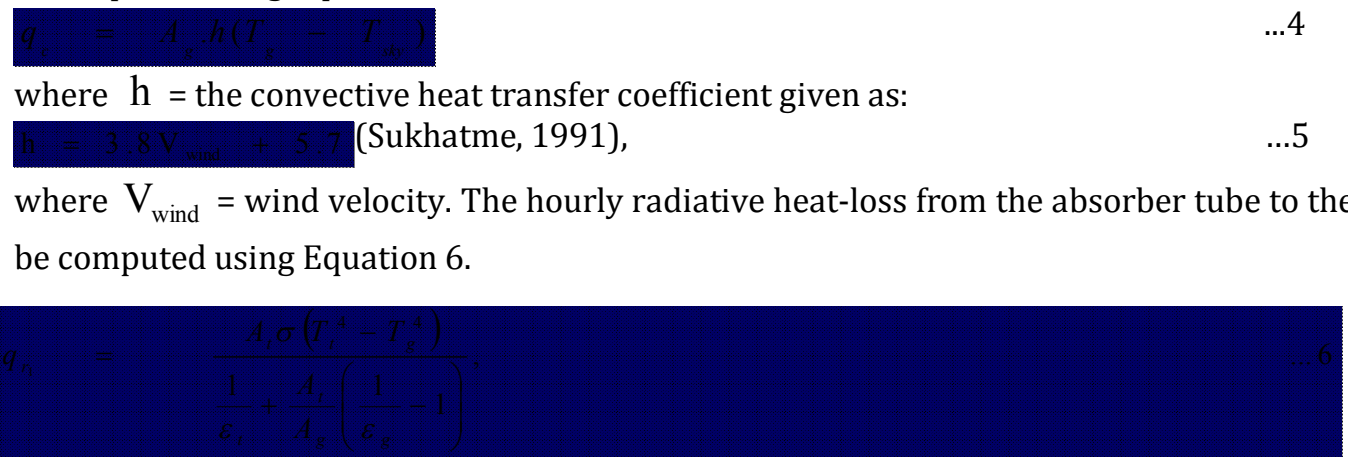

where $A_{t}=$ the surface area of the absorber-tube, $T_{t}=$ temperature of the absorber-tube and $\varepsilon_{t}=$ emittance of the absorber-tube materialgiven as:

$\varepsilon=\sigma \mathrm{T}_{\mathrm{g}} 4$ 
where $\sigma=$ Stefan-Boltzmann's constant $\left(\sigma=5.67 \times 10^{-8} \mathrm{~W} / \mathrm{M}^{2} \mathrm{~K}^{4}\right), \mathrm{T}=$ absolute temperature $\left({ }^{\circ} \mathrm{K}\right)$ of the surface. The hourly conductive/ convective heat-losses, by the working fluid inside the absorber-tube $\left(\mathrm{q}_{1}\right)$ can be computed using Equation 8 , as

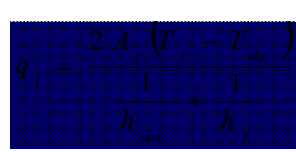

The Energy transfer to the receiver ( $\left.Q_{\text {input }}\right)$ can be computed as follows:

$\mathrm{Q}=\mathrm{M} \cdot \mathrm{C}_{\mathrm{P}}\left(\mathrm{T}_{1}-\mathrm{T}_{2}\right)$

Where $\mathrm{M}=\rho \mathrm{v}=\pi /{ }_{6} \mathrm{D} \cdot \rho$

$\mathrm{Q}=\pi /{ }_{6} \mathrm{D} \cdot \rho \cdot \mathrm{Cp}\left(\mathrm{T}_{1}-\mathrm{T}_{2}\right)$

The absorber-tube is made of copper tube, coated with black paint. The outer diameter of the absorber tube, $\mathrm{d}$, is given as $0.013 \mathrm{~m}$. With a thickness of the absorber-tube, $x_{t}=0.0015$ the inner diameter of the absorber-tube, $d_{1}$, can be computed as follows:

$d_{1}=d-2 \cdot x$,

The outer diameter of the enveloping glass-cover is given as $.045 \mathrm{~m}$. With a thickness of $\mathrm{x}_{\mathrm{t}}=0.011$

The fluid is Air and assuming a mean temperature of the fluid to be $45.43{ }^{\circ} \mathrm{C}=318.43 \mathrm{~K}$, the following properties are selected from (Churchill and Chu 1995): $\quad$ Density $\left(\rho_{f}\right)=1.009 \mathrm{~kg} / \mathrm{m}^{3}$, Thermal conductivity $(K)=$ $0.03003 \mathrm{~W} / \mathrm{m} \cdot \mathrm{K}$, Prandtl number $(\operatorname{Pr})=0.697$, Specific heat capacity $\left(C_{p_{f}}\right)=1.0090 J / \mathrm{kg} \cdot K$ and $\operatorname{Viscosity}\left(\mu_{f}\right)=$ $2.075 \times 10^{-5} \mathrm{~kg} / \mathrm{m} . \mathrm{s}$, Grashof number $\left(\mathrm{Gr}_{\mathrm{d}}\right)$ can be computed using equation 5 (Kreida and Frank, 1981).

$G r_{d}=\frac{\rho_{f}^{2} g \beta \Delta T d_{1}^{3}}{\mu^{2}}$

where density of the fluid $\left(\rho_{f}\right)=1.009 \mathrm{~kg} / \mathrm{m}^{3}$, gravitational constant $(g)=9.81 \mathrm{~m} / \mathrm{s}$, inner diameter of the absorbertube $\left(d_{1}\right)=0.0100 \mathrm{~m}$ and coefficient of expansion of the fluid $(\beta)$ equals the reciprocal of $T_{f}$. Therefore, $\beta=\frac{1}{318.43}$.

Assuming a mean temperature of the absorber-tube $\left(T_{t}\right)$ to be $48.14{ }^{\circ} \mathrm{C}$ and the mean temperature of the fluid ( $T_{f}$ ) to be $45.43{ }^{\circ} \mathrm{C}$. Therefore, the mean temperature difference is computed as follows:

$\Delta T=T_{t}-T_{f}=48.14-45.43=2.71{ }^{\circ} \mathrm{C}$.

Grashof number, $G r_{d}=\frac{(1.009)^{2} \times 9.81 \times \frac{1}{318.43} \times 2.71 \times(0.0100)^{3}}{\left(2.075 \times 10^{-5}\right)^{2}}=197.41$

The expression used for the calculation of Nusselt number is given by Churchill and Chu (1995). It is written in equation 9 as follows:

$N u^{1 / 2}=0.60+0.387\left\{\frac{G r_{d} \operatorname{Pr}}{\left[1+(0.559 / \operatorname{Pr})^{9 / 16}\right]^{6 / 9}}\right\}^{1 / 6}$ for $10^{-5}<G r . \operatorname{Pr}<10^{12} \quad \ldots 13$ Correspondingly;

Therefore,

$N u^{1 / 2}=0.60+0.387\left\{\frac{(197.41 \times 0.697)}{\left[1+(0.559 / 0.697)^{9 / 16}\right]^{6 / 9}}\right\}^{1 / 6}=1.68$

$h_{f}=\frac{N u \times K_{f}}{d_{1}}=\frac{1.68 \times 0.03003}{0.0100}=5.05 \mathrm{~W} / \mathrm{m}^{2} . K$

where $h_{f}=$ Convective heat-transfer coefficient for the inside of the absorber-tube, $d_{1}=$ inner diameter of the absorbertube and $K_{f}=$ thermal conductivity of the fluid.

The hourly thermal efficiency

The hourly thermal efficiency $(\boldsymbol{\eta})$ of the collector is given by:

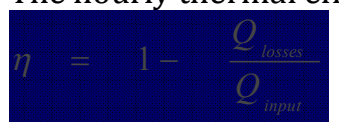

\section{Test Result and Discussion}

The relative humidity and wind speed were measured with the aid of meteorological instrument at the Bauchi State air strip. The relative humidity and the wind-speed readings were taken hourly from 09:00 to 16:00 hours and the results obtained are in $\%$ and $\mathrm{m} / \mathrm{s}$ respectively as presented in Table 3 and Table 4 respectively. 


\begin{tabular}{|c|c|c|c|c|c|c|c|c|}
\hline Date & $\mathbf{9 : 0 0 h r}$ & $\mathbf{1 0 : 0 0 h r}$ & $\mathbf{1 1 : 0 0 h r}$ & $\mathbf{1 2 : 0 0 h r}$ & $\mathbf{1 3 : 0 0 h r}$ & $\mathbf{1 4 : 0 0 h r}$ & $\mathbf{1 5 : 0 0 h r}$ & $\mathbf{1 6 : 0 0 h r}$ \\
\hline $11 / 11 / 2012$ & 28.00 & 24.00 & 21.00 & 22.00 & 22.00 & 22.00 & 24.00 & 25.00 \\
\hline $12 / 11 / 2012$ & 22.00 & 21.00 & 22.00 & 23.00 & 22.00 & 23.00 & 24.00 & 27.00 \\
\hline $13 / 11 / 2012$ & 21.00 & 16.00 & 17.00 & 17.00 & 16.00 & 16.00 & 19.00 & 23.00 \\
\hline $14 / 11 / 2012$ & 18.00 & 18.00 & 18.00 & 14.00 & 15.00 & 17.00 & 20.00 & 20.00 \\
\hline $15 / 11 / 2012$ & 14.00 & 17.00 & 17.00 & 16.00 & 15.00 & 16.00 & 17.00 & 18.00 \\
\hline $16 / 11 / 2012$ & 16.00 & 16.00 & 17.00 & 15.00 & 15.00 & 15.00 & 18.00 & 22.00 \\
\hline $11 / 17 / 2012$ & 14.00 & 16.00 & 16.00 & 13.00 & 13.00 & 14.00 & 17.00 & 23.00 \\
\hline MEAN & 19.00 & 18.29 & 18.29 & 17.14 & 16.86 & 17.57 & 19.86 & 22.57 \\
\hline
\end{tabular}

Table 3: Tabulated Values of Relative Humidity (\%)

\begin{tabular}{|c|c|c|c|c|c|c|c|c|}
\hline Date & $\mathbf{9 : 0 0 h r}$ & $\mathbf{1 0 : 0 0 h r}$ & $\mathbf{1 1 : 0 0 h r}$ & $\mathbf{1 2 : 0 0 h r}$ & $\mathbf{1 3 : 0 0 h r}$ & $\mathbf{1 4 : 0 0 h r}$ & $\mathbf{1 5 : 0 0 h r}$ & $\mathbf{1 6 : 0 0 h r}$ \\
\hline $11 / 11 / 2012$ & 4.00 & 0.00 & 12.00 & 0.00 & 0.00 & 0.00 & 0.00 & 12.00 \\
\hline $12 / 11 / 2012$ & 14.00 & 14.00 & 14.00 & 20.00 & 12.00 & 12.00 & 14.00 & 16.00 \\
\hline $13 / 11 / 2012$ & 12.00 & 14.00 & 20.00 & 16.00 & 16.00 & 12.00 & 8.00 & 6.00 \\
\hline $14 / 11 / 2012$ & 0.00 & 10.00 & 10.00 & 16.00 & 10.00 & 12.00 & 0.00 & 0.00 \\
\hline $15 / 11 / 2012$ & 10.00 & 12.00 & 10.00 & 8.00 & 8.00 & 10.00 & 12.00 & 12.00 \\
\hline $16 / 11 / 2012$ & 0.00 & 0.00 & 0.00 & 0.00 & 12.00 & 8.00 & 8.00 & 4.00 \\
\hline $11 / 17 / 2012$ & 0.00 & 0.00 & 0.00 & 0.00 & 0.00 & 0.00 & 12.00 & 8.00 \\
\hline MEAN & 5.70 & 7.14 & 9.43 & 8.57 & 8.29 & 7.71 & 7.71 & 8.29 \\
\hline
\end{tabular}

Table 4: Tabulated Values of the Wind Speed (M/S)

A digital thermometer was used for taking the readings of the hourly ambient temperature, the hourly temperature for the enveloping glass-cover, the hourly temperature changes for the absorber-tube and the fluid in ${ }^{\circ} \mathrm{C}$ presented in Tables4.3, 4.4, 4.5 and 4.6

\begin{tabular}{|c|c|c|c|c|c|c|c|c|}
\hline Date & $\mathbf{9 : 0 0 h r}$ & $\mathbf{1 0 : 0 0 h r}$ & $\mathbf{1 1 : 0 0 h r}$ & $\mathbf{1 2 : 0 0 h r}$ & $\mathbf{1 3 : 0 0 h r}$ & $\mathbf{1 4 : 0 0 h r}$ & $\mathbf{1 5 : 0 0 h r}$ & $\mathbf{1 6 : 0 0 h r}$ \\
\hline $11 / 11 / 2012$ & 33.00 & 35.00 & 36.00 & 37.00 & 36.00 & 37.00 & 36.00 & 35.00 \\
\hline $12 / 11 / 2012$ & 35.00 & 35.00 & 36.00 & 39.00 & 38.00 & 36.00 & 35.00 & 33.00 \\
\hline $13 / 11 / 2012$ & 32.00 & 33.00 & 36.00 & 40.00 & 38.00 & 35.00 & 34.00 & 32.00 \\
\hline $14 / 11 / 2012$ & 30.00 & 29.00 & 35.00 & 39.00 & 36.00 & 37.00 & 39.00 & 36.00 \\
\hline $15 / 11 / 2012$ & 32.00 & 33.00 & 36.00 & 40.00 & 37.00 & 35.00 & 33.00 & 33.00 \\
\hline $16 / 11 / 2012$ & 29.00 & 33.00 & 33.00 & 38.00 & 35.00 & 34.00 & 33.00 & 32.00 \\
\hline $11 / 17 / 2012$ & 30.00 & 33.00 & 34.00 & 39.00 & 37.00 & 35.00 & 35.00 & 33.00 \\
\hline MEAN & 31.16 & 33.00 & 35.00 & 38.86 & 36.71 & 35.57 & 35.00 & 33.43 \\
\hline \multicolumn{8}{|c|}{ Table 5: Tablated Values of Ambient Temperature (Oc) }
\end{tabular}

\begin{tabular}{|c|c|c|c|c|c|c|c|c|}
\hline Date & $\mathbf{9 : 0 0 h r}$ & $\mathbf{1 0 : 0 0 h r}$ & $\mathbf{1 1 : 0 0 h r}$ & $\mathbf{1 2 : 0 0 h r}$ & $\mathbf{1 3 : 0 0 h r}$ & $\mathbf{1 4 : 0 0 h r}$ & $\mathbf{1 5 : 0 0 h r}$ & $\mathbf{1 6 : 0 0 h r}$ \\
\hline $11 / 11 / 2012$ & 36.00 & 37.00 & 38.00 & 39.00 & 38.00 & 39.00 & 38.00 & 37.00 \\
\hline $12 / 11 / 2012$ & 37.00 & 37.00 & 38.00 & 41.00 & 40.00 & 38.00 & 38.00 & 36.00 \\
\hline $13 / 11 / 2012$ & 34.00 & 35.00 & 38.00 & 43.00 & 40.00 & 37.00 & 37.00 & 35.00 \\
\hline $14 / 11 / 2012$ & 33.00 & 32.00 & 37.00 & 40.00 & 38.00 & 39.00 & 40.00 & 38.00 \\
\hline $15 / 11 / 2012$ & 34.00 & 35.00 & 38.00 & 42.00 & 39.00 & 37.00 & 36.00 & 36.00 \\
\hline $16 / 11 / 2012$ & 32.00 & 35.00 & 36.00 & 40.00 & 37.00 & 37.00 & 36.00 & 35.00 \\
\hline $17 / 11 / 2012$ & 33.00 & 36.00 & 36.00 & 41.00 & 39.00 & 37.00 & 37.00 & 36.00 \\
\hline MEAN & 34.14 & 35.29 & 37.29 & 40.86 & 38.71 & 37.71 & 37.43 & 36.14 \\
\hline
\end{tabular}

Table 6: Tabulated Values of the Temperature of the Glass-Cover $\left({ }^{\circ} \mathrm{c}\right)$

\begin{tabular}{|c|c|c|c|c|c|c|c|c|}
\hline Date & $\mathbf{9 : 0 0 h r}$ & $\mathbf{1 0 : 0 0 h r}$ & $\mathbf{1 1 : 0 0 h r}$ & $\mathbf{1 2 : 0 0 h r}$ & $\mathbf{1 3 : 0 0 h r}$ & $\mathbf{1 4 : 0 0 h r}$ & $\mathbf{1 5 : 0 0 h r}$ & $\mathbf{1 6 : 0 0 h r}$ \\
\hline $11 / 11 / 2012$ & 53.00 & 55.00 & 56.00 & 58.00 & 62.00 & 60.00 & 54.00 & 48.00 \\
\hline $12 / 11 / 2012$ & 53.00 & 55.00 & 58.00 & 62.00 & 63.00 & 59.00 & 50.00 & 45.00 \\
\hline $13 / 11 / 2012$ & 46.00 & 50.00 & 50.00 & 59.00 & 53.00 & 53.00 & 50.00 & 43.00 \\
\hline $14 / 11 / 2012$ & 42.00 & 40.00 & 50.00 & 60.00 & 58.00 & 53.00 & 51.00 & 47.00 \\
\hline $15 / 11 / 2012$ & 46.00 & 50.00 & 51.00 & 68.00 & 54.00 & 51.00 & 48.00 & 46.00 \\
\hline $16 / 11 / 2012$ & 45.00 & 50.00 & 49.00 & 58.00 & 53.00 & 54.00 & 53.00 & 44.00 \\
\hline $17 / 11 / 2012$ & 52.00 & 55.00 & 56.00 & 64.00 & 57.00 & 54.00 & 56.00 & 50.00 \\
\hline MEAN & 48.14 & 50.71 & 52.86 & 61.29 & 57.14 & 54.86 & 51.71 & 46.14 \\
\hline
\end{tabular}

Table 7: Tabulated Values of the Temperature of the Absorber-Tube ( $\left.{ }^{\circ} \mathrm{C}\right)$ 


\begin{tabular}{|c|c|c|c|c|c|c|c|c|}
\hline Date & $\mathbf{9 : 0 0 h r}$ & $\mathbf{1 0 : 0 0 h r}$ & $\mathbf{1 1 : 0 0 h r}$ & $\mathbf{1 2 : 0 0 h r}$ & $\mathbf{1 3 : 0 0 h r}$ & $\mathbf{1 4 : 0 0 h r}$ & $\mathbf{1 5 : 0 0 h r}$ & $\mathbf{1 6 : 0 0 h r}$ \\
\hline $11 / 11 / 2012$ & 44.00 & 47.00 & 51.00 & 53.00 & 54.00 & 56.00 & 49.00 & 45.00 \\
\hline $12 / 11 / 2012$ & 46.00 & 47.00 & 52.00 & 58.00 & 54.00 & 50.00 & 47.00 & 43.00 \\
\hline $13 / 11 / 2012$ & 44.00 & 48.00 & 51.00 & 126.00 & 52.00 & 50.00 & 47.00 & 43.00 \\
\hline $14 / 11 / 2012$ & 47.00 & 41.00 & 52.00 & 60.00 & 58.00 & 53.00 & 51.00 & 46.00 \\
\hline $15 / 11 / 2012$ & 46.00 & 49.00 & 53.00 & 59.00 & 54.00 & 50.00 & 49.00 & 48.00 \\
\hline $16 / 11 / 2012$ & 44.00 & 50.00 & 50.00 & 57.00 & 52.00 & 51.00 & 48.00 & 46.00 \\
\hline $17 / 11 / 2012$ & 47.00 & 51.00 & 53.00 & 58.00 & 55.00 & 52.00 & 53.00 & 48.00 \\
\hline MEAN & 45.43 & 47.57 & 51.71 & 57.29 & 54.43 & 51.71 & 49.14 & 45.57 \\
\hline
\end{tabular}

Table 8: Tabulated Values of the Temperature of the Fluid $\left({ }^{\circ} \mathrm{C}\right)$

\begin{tabular}{|c|c|c|c|c|c|c|c|c|}
\hline Date & $\mathbf{9 : 0 0 h r}$ & $\mathbf{1 0 : 0 0 h r}$ & $\mathbf{1 1 : 0 0 h r}$ & $\mathbf{1 2 : 0 0 h r}$ & $\mathbf{1 3 : 0 0 h r}$ & $\mathbf{1 4 : 0 0 h r}$ & $\mathbf{1 5 : 0 0 h r}$ & $\mathbf{1 6 : 0 0 h r}$ \\
\hline Mean & 250.82 & 294.57 & 365.91 & 394.12 & 377.09 & 335.83 & 280.90 & 226.21 \\
\hline
\end{tabular}

Table 9: Tabulated Average Hourly Heat-Energy Input to the Receiver ( $Q_{\text {input }}$ )

\begin{tabular}{|c|c|c|c|c|c|c|c|c|}
\hline Parameter & $\mathbf{9 : 0 0 h r}$ & $\mathbf{1 0 : 0 0 h r}$ & $\mathbf{1 1 : 0 0 h r}$ & $\mathbf{1 2 : 0 0 h r}$ & $\mathbf{1 3 : 0 0 h r}$ & $\mathbf{1 4 : 0 0 h r}$ & $\mathbf{1 5 : 0 0 h r}$ & $\mathbf{1 6 : 0 0 h r}$ \\
\hline $\mathrm{q}_{\mathrm{r} 1}$ & 0.0676 & 0.122 & 0.152 & 0.817 & 0.403 & 0.258 & 0.0972 & 0.0152 \\
\hline $\mathrm{q}_{\mathrm{r} 2}$ & 0.0430 & 0.0357 & 0.0446 & 0.0562 & 0.0457 & 0.0448 & 0.0477 & 0.0479 \\
\hline $\mathrm{q}_{\mathrm{c}}$ & 11.79 & 11.95 & 14.51 & 13.44 & 13.06 & 12.95 & 12.48 & 14.22 \\
\hline $\mathrm{q}_{1}$ & 0.0105 & 0.0162 & 0.0196 & 0.0247 & 0.0227 & 0.0231 & 0.0175 & 0.0145 \\
\hline $\mathrm{Q}_{\text {input }}$ & 250.82 & 294.57 & 365.91 & 394.12 & 377.09 & 335.83 & 280.90 & 226.21 \\
\hline $\mathrm{Q}_{\text {loss }}$ & 11.90 & 12.12 & 14.73 & 14.34 & 13.53 & 13.27 & 12.64 & 14.30 \\
\hline$\eta_{\exp }$ & 95.25 & 95.88 & 95.97 & 96.36 & 96.41 & 96.05 & 95.50 & 93.68 \\
\hline
\end{tabular}

Table 10: Presents Values of Calculated Parameters of the Hourly Thermal Efficiency $\left(H_{\text {exp }}\right)$ of the Solar Parabolic-trough Concentrating Collector

\subsection{Discussion}

The results of the experiment show that temperature of the enveloping glass-cover, the temperature of the absorber-tube and the temperature of the fluid increases uniformly with time from 09: 00 hour to a maximum at 12.00hour and then decreases uniformly till 16.00hour. This is attributed to the wind speed and the relative humidity patterns experienced within the period which also affect the efficiency.

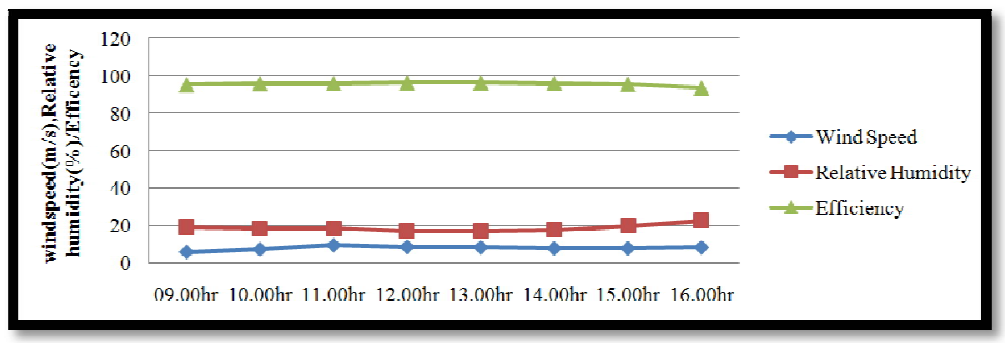

Figure 5: Graph Relationship between Wind Speeds, Relative Humidity and Efficiency

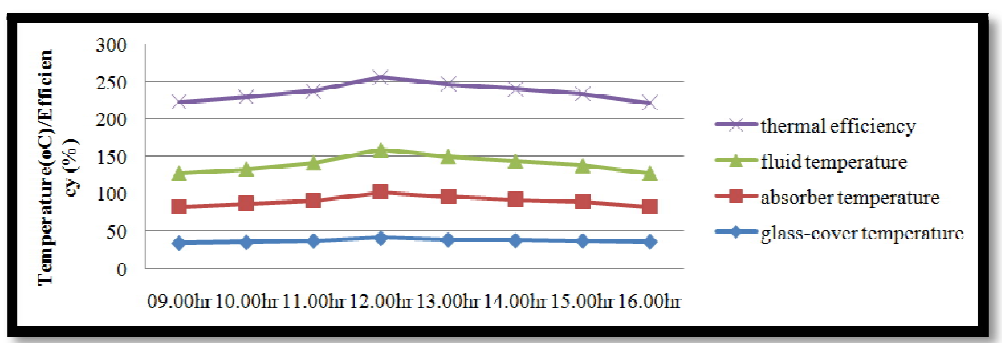

Figure 6: Graph Relationship between Temperature and Efficiency

\section{Conclusion}

Limited fossil energy resources, which account for serious air pollution, will be exhausted in the near future. Therefore, it is urgent to develop a new renewable and clean energy system. A solar parabolic-trough collector, producing power from solar energy, is proven to be a good choice. From the determination of the effect of relative humidity and wind 
speed on the performance of a solar parabolic-tough collector system model TE 38 in Bauchi, it shows that, the higher the wind speed is the higher the radiative heat-loss which also affects the efficiency. The effect of relative humidity on efficiency of the solar parabolic-trough collector shows that efficiency is high during low relative humidity. This indicate that Relative humidity and wind speed affects the efficiency and as such the performance of the solar parabolic -trough collector system. However, the effect of wind speed and relative humidity is observed to be minor as long as the variations are not too extreme. Hence thepotential of solarparabolic-troughcollectorsystemforsustainableelectricitygenerationin Bauchi isvery promising The recommendation for future work is that the experiment days be extended beyond the number of days used in this research, so as to enhance effective graphical comparison of the relative humidity and wind speed with the efficiency.

\section{References}

i. Adeyemi k. O and Asere A. A (2007): Household energy consumption in Bauchi, Nigeria Journal of Solar Energy Vol. 18 Pg 28

ii. Agbo S. N, Ezema F. I and Ugwuoke P. E (2007): Solar radiation estimate from relative humidity-based model. Nigeria Journal of Solar Energy Vol. 18 Pg 134-138

iii. Ahmed Khaled (2012): Technical and Economic Performance of Parabolic Trough in Jordan, Faculty of Engineering at Cairo University Egypt. http://www.masterthesis-Ahmed-yasin.pdf

iv. Churchill, S. W., and Chu, H. S., (1995), Correlating equations for laminar and turbulent free convection from a vertical plate, International Journal of Heat Mass Transfer, Vol. 18, Pg 1323-1333

v. Dandakouta H, Egbo, G and Asere A. A (2007): The effect of anisotropic multiple scattering of solar radiation on the performance of a solar water heater, Nigeria Journal of Solar Energy Vol. 18 Pg 121-128

vi. Daniel Horst (2012): Performance Stimulation for Parabolic Trough Concentrating Solar Power Plants and Export Scenario Analysis for North Africa, Faculty of Engineering Cairo University Giza Egypt. http:// www.masterthesis-Daniel-horst.pdf

vii. Dincar, I. (2003): The Role of Energy in Energy Policy Making. Energy Policy Vol.(30):137-149

viii. Duffie John A. and William A. Bechman, (1974), 'Solar Energy Thermal Processes'

ix. Egbo, G.,(2008), Experimental Performance Evaluation of a Solar parabolic-Trough Concentrating collector (model TE 38), International Journal of pure and Applied Science, Vol. 2(1), pg 55-64

x. Ettah, E.B, Udoimuk, A.B, Obiefuna, J. N and Opara, F. E (2012): The Effect of Relative Humidity on the Efficiency of Solar Panels inCalabar, Nigeria, Universal Journal of Management and Social Sciences Vol. 2, No.3

xi. http://www.solarpaces.org/CSP_Technology/docs/solar_trough.pdf

xii. Igboekwe M. U and Agbasonu J. N (2006): Optimization of a solar module for the generation of enhanced electricity power, International Conference of Solar Energy Society of Nigeria, Conference Proceeding Vol. 1 Pg 130-135

xiii. Jesuleye O.A and Siyanbola W.O 9(2007): Solar electricity demand analysis for improved access to energy services in Nigeria, Nigeria Journal of Solar Energy Vol. 19 No. 1 Pg 136.

xiv. Kearney, David W., and Miller, Charles E. SEGS VI: Technical Evaluation of Project

xV. Feasibility. Submitted to Luz Solar Partners VI. January 1988.

xvi. Kreida, J. F., and Frank, K., (1981) Solarheating design processes. Solar Energy Handbook. McGraw-Hill Book Company, U.S.A., pp. 67-103.

xvii. Obienusi E. A (2006): Solar energy for enhanced economic activities solar energy need in Nigeria review, International Conference of Solar Energy Society of Nigeria, Conference Proceeding Vol. 1 Pg 51-57.

xviii. Olusegun, A. Bola, A. Goh, C. L. Ohiwerei, I. (1980): Certificate Physical and Human Geography

xix. for senior Secondary Schools. 201-202 University Press. Nigeria

xx. Rabah, K. V. O. (2005): Integrated Solar Energy System for Rural Electrification in Kenya, Renewable Energy Vol.(30)23-42

xxi. Soteris A Kalogirou (2004): Solar Thermal Collectors and Application. Progress in Energy and Combustion Science 30,231-295

xxii. Sukhatme, S. P. (1991) Solarenergy: Principles of thermal collection and storage. Tata McGraw-Hill Publishing Company Limited, New Delhi. pp. 23-31.

xxiii. www.solartrough.com/pdf

xxiv. www.sunraysolar.com

xxv. XinpingZhon, Jiakuan Yang, Bo Xiao and Xiaoyan Shi (2008): Special Climate around a commercial Solar Chimney Power Plant, Journal of Energy Engineering. 